\title{
HEMIBRYCON GUEJARENSIS, A NEW SPECIES FROM THE GÜEJAR RIVER, ORINOCO BASIN, COLOMBIA (CHARACIFORMES: CHARACIDAE) WITH A REVIEW THE POPULATIONS IDENTIFIED AS HEMIBRYCON METAE
}

\author{
HEMIBRYCON GUEJARENSIS, A NEW SPECIES FROM THE GÜEJAR RI- \\ VER, ORINOCO BASIN, COLOMBIA (CHARACIFORMES: CHARACIDAE) \\ WITH A REVIEW THE POPULATIONS IDENTIFIED AS HEMIBRYCON \\ METAE
}

\author{
César Román-Valencia ${ }^{1 *}$, Raquel I. Ruiz-C. ${ }^{1} \&$ Donald C. Taphorn B. ${ }^{2}$ \\ 1. Laboratorio de Ictiología, Universidad del Quindío, A. A. 2639, Armenia, Quindío, \\ Colombia. Email: ceroman@uniquindio.edu.co,zutana 1@yahoo.com \\ 2. 1822 North Charles Street, Belleville, Illinois, 62221, USA. Email: taphorn@gmail.com
}

*Corresponding autor: ceroman@uniquindio.edu.co

\begin{abstract}
Hemibrycon guejarensis, new species, is described from the Güejar River, La Macarena mountain range, upper Guaviare River drainage, Colombia. The new species is distinguished from most cis-Andean congeners (H. jabonero Lake Maracaibo and adjacent Caribbean drainages, H. metae which is found in the Guavio River, some Orinoco and Caribbean River drainages in Venezuela, and H. taeniurus from Trinidad and adjacent mainland drainages in Venezuela) in having ii, 7, i dorsal-fin rays (vs. ii, 8). H. guejarensis is further distinguished from $H$. taeniurus and H. jabonero, in having a wider second pigment layer in the humeral spot (covering 3 vs. 2 scale widths). H. guejarensis is very similar to H. metae (an allopatric species also present in streams of the Orinoco River Basin in Venezuela and Colombia and some Venezuelan Caribbean drainages). Hemibrycon guejarensis is distinguished by the orientation of the dorsal canal which crosses the humeral spot transversely vs. horizontally across dorsal part of spot in the holotype of H. metae and Orinoco and Caribbean populations. H. guejarensis differs from $H$. metae in having the tip of the pectoral fin passing the pelvic-fin insertions (vs. pectoral fin tip not reaching pelvic-fin insertions). We identify populations previously considered as Hemibrycon metae from Venezuelan Orinoco River Basin piedmont streams and Caribbean drainages to be instead H. jabonero and $H$. taeniurus. Careful analysis of these populations indicated that all of them differ from the H. metae holotype and topotypic specimens in pelvic fin and postorbital lengths.
\end{abstract}

Key words: Fishes, Teleostei, Stevardiinae, Taxonomy, South America.

Cómo citar:

Román et al. (2017) HEMIBRYCON GUEJARENSIS, A NEW SPECIES FROM THE GÜEJAR RIVER, ORINOCO BASIN, COLOMBIA (CHARACIFORMES: CHARACIDAE) WITH A REVIEW THE POPULATIONS IDENTIFIED AS HEMIBRYCON METAE. Revista de Investigaciones de la Universidad del Quindío. Vol 29, pp.38-52. 


\section{RESUMEN.}

Hemibrycon guejarensis, una nueva especie de pez, se describe del Río Guejar, Serranía de la Macarena, sistema del Río Guaviare, Colombia. La nueva especie se distingue de muchos congéneres Andinos (H. jabonero del lago de Maracaibo y adyacentes drenajes del Caribe, H. metae la cual se encuentra en el Rio Guavio, algunos drenajes del Orinoco y Caribe en Venezuela, y H. taeniurus de Trinidad y drenajes adyacentes en Venezuela) en poseer ii,7,i radios en aleta dorsal (vs. ii,8). H. guejarensis se distingue también de $H$. taeniurus y $H$. jabonero, en presentar la segunda capa de pigmentos de la mancha humeral ancha (cubre 3 vs. 2 escamas a lo ancho). H. guejarensis es muy parecida a H. metae (especie alopátrica proveniente del río Guavio y reconocida en quebradas o caños en la cuenca del Orinoco en Venezuela y Colombia y algunos drenajes del Caribe Venezolano). Hemibrycon guejarensis se distingue por la orientación del canal que cruza la mancha humeral transversalmente vs. horizontalmente alrededor de la parte dorsal de la mancha en el holotipo de $H$. metae y poblaciones del Orinoco y Caribe. H. guejarensis se distingue de H. metae en presentar el extremo de las aletas pectorales que sobre pasan las inserciones de las aletas pélvicas (vs. extremo de la aleta pectoral no alcanzan las inserciones de las aletas pélvicas). Identificamos poblaciones previamente consideradas como Hemibrycon metae del piedemonte de la cuenca del Río Orinoco en Venezuela y drenajes del Caribe que se identifican como H. jabonero y H. taeniurus. Análisis detallado de estas poblaciones indicaron que todas se diferencian del holotipo de H. metae y material topotipico en las longitudes postorbital y aletas pélvicas.

Palabras claves: Peces, Teleostei, Stevardiinae, Taxonomía, Sur America.

\section{INTRODUCTION.}

The genus Hemibrycon is a group of freshwater characid fish species that are typically found in clear freshwater habitats in the rivers of the Pacific basins in Panama, coastal Caribbean basins in Colombia and Venezuela, the Lake Maracaibo and Orinoco River basins in Venezuela and Colombia, rivers of Trinidad and Tobago, coastal basins of French Guiana and Suriname and upper Amazon River drainages of Bolivia, Colombia, Peru and Ecuador (Bertaco et al., 2007; Bertaco \& Malabarba, 2010; García-Alzate et al.,2015; Román-Valencia et al., 2006; 2007; 2014; Román-Valencia \& Ruiz-C., 2007). The wide geographic distribution, and unevenly distributed species diversity of Hemibrycon requires different explanatory mechanisms and probably is a result of both sympatric and allopatric speciation processes. Recent generic analysis (Bertaco et al., 2010, Thomas et al, 2017) did not adequately address the complex cryptic diversity of the group.

Bertaco \& Malabarba (2010) identified Hemibrycon populations from small coastal river drainages in the Golfo de Paria, Venezuela as $H$. metae rather than $H$. taeniurus (found on the nearby island of Trinidad). However, those specimens were all small, $(<51.3 \mathrm{~mm}$ $\mathrm{SL}$ ), making it difficult to compare body measurements with available (larger) specimens of $H$. metae from the Orinoco River Basin. Based on the identification of those small specimens, they extended the known distribution of $H$. metae to the Caribbean. In this paper we review the populations identified as $\mathrm{He}$ mibrycon metae from the Orinoco River Basin and
Venezuelan Caribbean drainages and describe one new species from Macarena, Colombia.

\section{MATERIAL AND METHODS.}

Measurements and counts follow Román-Valencia et al. (2010), and are presented as percentages of standard length (SL) except for subunits of head which are presented as percentages of head length (HL). The standard length is recorded until the posterior edge of the hypurals. In count ranges, values for the holotype are indicated with an asterisk $(*)$. Counts and measurements were taken on the left side of specimens when possible. Osteological studies were made on cleared and stained specimens (C\&S) prepared according to Taylor \& Van Dyke (1985) and Song \& Parenti (1995). Bone nomenclature follows Weitzman (1962), Vari (1995), and Ruiz-C. \& Román-Valencia (2006). Specimens are deposited in the Auburn University Museum Fish Collection, Auburn, Alabama (AUM), and the Ichthyology Laboratory at the Universidad del Quindío, Armenia, Colombia (IUQ). In the lists of paratypes, the number of individuals is given in parentheses immediately after the catalog number. Institutional acronyms for comparative material follow Sabaj-Perez (2016). Humeral spot pigmentation configurations use the terminology proposed by Román-Valencia et al. (2015) and Ruiz et al. (2018).

\section{MATERIAL EXAMINED.}

Hemibrycon beni: All from Bolivia (see Arcila-M., 2008). UMSS 09585, 18, 35.2-82.6 mm SL, Amazonas/Madera/Beni/Bopo, rio Pekheñkhara, Imanblaya; 
3 Jan. 1990. UMSS 0890, 50, 47.3-75.4 mm SL, Amazonas/Beni/Madera/Kaka, afluente Taipiplaya-Taipiplaya; 3 Oct. 2008. UMSS 10027, 5, 22.6-101.5 mm SL, Amazonas/Beni, Madera/Bopi, Trinidad Pampa; 18 Oct. 2009. H. boquiae (see Román-Valencia, 2001; Román-Valencia et al., 2006; 2009b; c; 2010; Román-Valencia \& Arcila-M., 2008; 2010). H. colombianus: (see Román-Valencia \& Ruiz, 2007; Román-Valencia \& Arcila-M., 2010). H. dariensis: (see Román-Valencia \& Ruiz-C., 2007). H. guppy: (see Román-Valencia \& Ruiz-C., 2007); BMNH 1906623, lectotype, 1. USNM 290406, 1, C\&S. USNM 290406, 7. H. helleri: (see Arcila-M., 2008). H. jabonero: (see Román-Valencia \& Ruiz-C., 2007; Román-Valencia \& Arcila-M., 2010). All from Venezuela, Mérida: MCNG 42720, 17, 64.0-90.2 mm SL, Chama River, Lake Maracaibo Basin; 14 Nov 2005. MCNG 7475, 2, 95.7-102.5 $\mathrm{mm} \mathrm{SL}$, road to Tovar, Uribante; $14 \mathrm{Nov}$ 2005. MCNG 24838, 12, 24.0-81.7 mm SL, Lake Maracaibo basin, Escalante River; 3 Mar 1991. H. metae: (see Román-Valencia et al., 2006; Román-Valencia \& Ruiz, 2007). Colombia: Holotipo CAS 23727, 1 $75.69 \mathrm{~mm}$ SL, río Guavio. No tipo: Casanare, Aguazul, Orinoco: IAvH 3122, 10, 47.6-93.9 mm SL, Chichaca Creek, tributary of Cachiza River; 1 Mar 1994. IAvH 3125, 33, 51.1-71.4 mm SL, Unete, Cravo Sur and Tua River drainage; 4 May 1996. IAvH 3129, 50, 49.3-78.7 mm SL, Cupiagu Creek, Unete River drainage; 4 Mar 1994. IAvH 2991,3 ,58.3-59.5 mm SL, Casanare, Rios Unete, Cusiana y Tua; 4 Mar 1994. IAvH 3124, 17,54.8-83.2 mm SL, cuencas rios Pauto, Tocaria, Chave y Cravo Sur, nov. 1995. IAvH 2986,3, 56.5-73.8 mm SL, Rios Pauto, Tocaria, Charre y Cravosur, Feb. Mar 1996. IAvH 2973, 7, 54.7-78.0 mm SL, Casanare, municipio de Aguazul, quebrada Palmicha, afluente Rio Cachiza. IAvH 3134, 4, 54.7-62.9 $\mathrm{mm}$ SL, Casanare, Rio Nunchia. All from Venezuela: MCNG 26774, 4, 38.1-47.1 mm SL, Barinas, Santa Barbara River, $3 \mathrm{~km}$ NE, Santa Barbara, Apure River basin; 1 Jan 1992. MCNG 48498, 38, 30.5-55.8 $\mathrm{mm}$ SL, Portuguesa, creek to north from Ospino, road to Estación La Reinosa-Apure; 3 Nov 1995. MCNG 54610, 20, 37.8-70.8 mm SL, Yaracuy, Sarare Creek $1 \mathrm{~km}$ from Hacienda Corozal; 14 Nov 2005. MHNLS 8070,52, 23.0-46.1 mm SL, Aragua, Rio Aragua (puente caño de los Becerros), 13 Feb 1991. MHNLS 8091,40, 26.4-46.6 mm SL, Aragua, Rio Aragua (puente caño de los Becerros), 13 Feb 1991. MBUCV 27652, 4, 52.6-64.3 mm SL, Carabobo, Grande River, Guatopo National Park; 20 Dec 1980. MBUCV 24896, 3, 59.8-65.1 mm SL, Carabobo, Valencia Lake basin, El Ercigue river, north of San Joaquin, Carabobo; 4 May 1991. MBUCV 22854, 18, 62.0-77.0 mm SL, Carabobo, Valencia Lake; 18 Jun 1968. MBUCV 22809, 5, 39.6-79.7 mm SL, Carabobo, Miquita River, $2 \mathrm{~km}$ south of Goaigoaza; 2 Dec 1969. EBRG 4324, 23, 52.3-97.6 mm SL, Aragua, Limón River, pozo 350 m NW of Profauna building, El Limón; 21 Mar 1990. EBRG 9953, 32, 48.9-66.1 mm SL, Carabobo, Morón River, old highway to Morón Reservoir; 30 Jun 2004. EBRG 9825, 5, 66.2-84.0 mm SL, Colorado River, afluente del rio Neveri, 25 May 2005. H. orcesi (see Román-Valencia \& Arcila-M., 2009). H. polyodon (see Román-Valencia \& Arcila-M., 2010). $H$. quindos (see Román-Valencia \& Arcila-M., 2010). H. rafaelense: (see Román-Valencia \& Arcila-M., 2008). $H$ santamartae (Román-Valencia et al., 2009b). $H$. surinamensis: (see Arcila-M., 2008). H. tridens: (see Arcila-M., 2008). H. yacopiae (see Román-Valencia \& Arcila-M., 2010). Hemibrycon sp. n. All from Venezuela: MCNG 5475, Portuguesa, Rio Bocono en Pozos. MCNG 54566, 46, 47.9-56.4 mm SL; Carabobo, El Samán on Alpargatón River, above sand quarry; 14 Nov 2005. MCNG 49655,8, 29.3-66.8, Rio Tesorero, sector Santa Rosa, aproximadamente $5 \mathrm{Km}$ del poblado Carabobo; 4 Feb 2002. MCNG 54589, 3, 48.8-63.5 mm SL; Yaracuy, Creek on Hacienda Guáquira; 14 Nov. 2005. MCNG 16972, 8, 34.4-68.3 $\mathrm{mm}$ SL; Cocotal River (or Cocollar) at Campo Elias before San Antonio, at mouth with Guarapiche River, San Juan River system; 14 Nov 2005. MCNG 43516, 19, 26.4-70.5 mm SL, Sucre, Río Cristalino; 20 Dec 1998. MCNG 19540, $27,46.2-70.5$ mm SL, afluente Rio San Juan a Santa Rosa, al Sur de Casanay, 14 Aug 1998. MCNG 43493, 14, 45.5-67.4 mm SL, Río La Palencia, afluente del río San Juan; 01 Sept 1998. MCNG 43512, 14, 40.1-59.9 mm SL, Sucre, Río Cristalino; 20 Dec 1998. MCNG 19693, 39, 35.9-58.6 mm SL, Sucre, Rio La Toma $6 \mathrm{Km} \mathrm{N}$ de crta. 4 a 9 Km oeste de Güiria; 13 Aug 1988. MCNG 54535, 6, 50.0-58.2 mm SL, Falcón, Carretera Principal Churuguara - Coro (nueva) puente en San Pablo, 19 Oct 2005. MCNG 54602, 16, 50.0-71.0 mm SL; Yaracuy, Hacienda Guáquira, upper Guáquira Creek at cement crossing; 14 Nov 2005.MCNG 49640, 5, 27.5-46.0 $\mathrm{mm}$ SL; Crucito River, Crucito Sector, $1 \mathrm{~km}$ from asphalt de road to Palma Sola; 16 Jan 2004.MBUCV 12530, 4, 49.6-69.5 mm SL; Miranda, Grande River 500m after Santa Cruz River, Guatopo National Park; 1 Mar 1981.MBUCV 9736, 1,66.4 mm SL; Monagas, San Juan River, Los Morros Caripito; 28 Apr 1977. EBRG 4546, 33, 36.6-74.0 mm SL, Parque Nacional 
Peninsula de Paria, Río Bautista, sector "Los Mangos", Estado Sucre, 22 de abril de 1993.EBRG 4541, 22 , 39.7-66.2 mm SL, Río Yoco-sector Los mangos Edo. Sucre, 23 de abril de 1993.EBRG 4544,38, 38.181.87 mm SL, Península de Paria, rio La Toma sector Los Mangos, edo. Sucre, 21 de abril de 1993.EBRG 7542, 10, 44.5-57.9 mm SL; Falcón, Sierra San Luis, Mitare River at road, old road between Cabure and San Luis; 28 Jun 1996.

\section{RESULTS}

\section{Analysis of nominal $H$. metae populations from Orinoco and Venezuelan Caribbean river draina- ges.}

Review of the populations of Hemibrycon metae from the Orinoco River Basin and Caribbean drainages in Venezuela indicated that these do not coincide with the holotype characters of $H$. metae (CAS 23727). In this sense, the populations of these drainages showed more affinity with other species $(H$. jabonero and $H$. taeniurus) present in the area (Caribbean and Orinoco), than with the holotype of $H$. metae which is from piedmont streams of the southern flank of the Andean Orinoco River Basin in Colombia (at 300-400 masl). It was found that individuals from populations identified as H. metae (Orinoco and Venezuelan Caribbean) are not similar in morphometric measurements, but although there is high overlap of these characters among the populations, they can be distinguished from the holotype and topotypic material of true $H$. metae, see Table 1.

Morphometric characters (Table 1) such as pelvic-fin length (greater than $20 \%$ vs. less than $18 \% \mathrm{SL}$ ) and postorbital length ( $48.5 \% \mathrm{HL}$ vs. less than $47 \% \mathrm{HL}$ ), show significant differences among populations of nominal $H$. metae and its holotype (Permanova: $\mathrm{F}=$ 16.58; $\mathrm{P}=0.0001$, Table 2). We find that true H. metae (based on examination of the holotype) differs from these populations in some morphological characters and also some osteological characters such as the length of the maxilla, which reaches the posterior edge of the second infraorbital (vs. ventral end of the maxilla not reaching a vertical through the posterior edge of the second infraorbital), second infraorbital short, not extending to between the maxilla and the third infraorbital (vs. second infraorbital extending to between the maxilla and the third infraorbital), area preventral angle (vs. arched, Fig 2).
Discriminant analysis indicated that $85.21 \%$ of divergence of these populations from the holotype of Hemibrycon metae was explained by the first two eigenvalues and revealed additional independent populations that have not yet been named (Fig. 1). Morphometric characters (Table 1), such as pelvic fin length (greater than $20 \mathrm{vs}$. less than $18 \% \mathrm{SL}$ ) and postorbital length (48.5 vs. less than $47 \%$ HL), show significant differences between these populations of nominal $H$. metae when compared with its holotype (Permanova: $\mathrm{F}=16.58, \mathrm{P}=0.0001$, Table 2 ). And so, to further recognize some of the cryptic diversity within nominal Hemibrycon metae, we describe below as new the population occurring in the upper Guaviare River drainage.

\section{Hemibrycon guejarensis n. sp.}

(Table 1-2; Figs. 1-4)

Holotype. IUQ 2484, female, 78.33 mm SL; Colombia: Meta: Vista Hermosa County, Buenavista village, Orinoco River basin, Guaviare River drainage, Blanco River system, Pringamosal Creek, $3^{\circ} 07^{\prime} 01^{\prime} \mathrm{N}$ 7352'19'W; 384 masl; C. Román-Valencia \& C. García A., 12 Jan 2009.

Paratypes. All from Colombia: Meta: Vista Hermosa County, Orinoco River basin, Guaviare River drainage: AUM 52888, 2, 40.8-49.3 mm SL; IUQ 2485, 24, 32.5-64.4 mm SL; IUQ 2483, 2 females C\&S, 53.4$56.4 \mathrm{~mm} \mathrm{SL}$; same data as holotype. IUQ 2486, 4, 59.0-67.1 mm SL; Guadualito Creek on La Palma farm, Buenavista village, $3^{\circ} 05^{\prime} 44^{\prime \prime} \mathrm{N} 73^{\circ} 52$ '35'W, 456 masl; C. Román-Valencia., R. Ruiz C., C. GarcíaA., 16 Jan 2009. IUQ 2487, 20, 27.8-60.6 mm SL; Guadualito Creek, Buenavista village, 305'34" N 7351'53”W, 384 masl; C. Román-Valencia, R. RuizC., C. García-A., 12 Jan 2009. IUQ 2488, 8, 26.2-43.5 $\mathrm{mm}$ SL; Cota 400 Creek, Buenavista village, $3^{\circ} 06^{\prime} 03^{\prime \prime}$ N 7351'57'W, 389 masl; C. Román-Valencia, R. Ruiz-C., C. García-A., 13 Jan 2009.IUQ 2489, 17, 31.2-72.3 mm SL; Buenavista Creek, Buenavista village, 306’30” N 7352’26”W; C. Román-Valencia, R. Ruiz-C., C. García-A., 13 Jan 2009. IUQ 2490, 9, 33.4-45.9 mm SL; Pringamosal Creek, $500 \mathrm{~m}$ north of school La Palestina, Palestina village; C. RománValencia, R. Ruiz-C., C. García-A., 9 Jan 2009. IUQ 2497, 5, 34.9-56.7 mm SL; Pringamosal Creek, $500 \mathrm{~m}$ upstream from school in La Palestina, Palestina village; C. Román-Valencia, R. Ruiz-C., C. García-A., 9 Jan 2009. IUQ 2567, 55, 34.3-62.8 mm SL; Guadualito Creek, Buenavista village, $3^{\circ} 05^{\prime} 39^{\prime \prime} \mathrm{N} 73^{\circ} 51^{\prime} 55^{\prime \prime} \mathrm{W}$, 
381 masl; C. Román-Valencia, R. Ruiz-C., C. GarcíaA., 3 Apr 2009. IUQ 2568, 3, 50.7-64.6 mm SL; Guadualito Creek, Buenavista village, 305'39” N 7351'55”W, 381 masl; C. Román-Valencia, R. RuizC., C. García-A., 3 Apr 2009.IUQ 2569, 1 male C\&S, $46.4 \mathrm{~mm}$ SL; Guadualito Creek, Buenavista village, 305'39'N 7351'55'W, 381 masl; C. Román-Valencia, R. Ruiz-C., C. García-A., 3 Apr 2009. IUQ 2610, 7, 48.3-63.3 mm SL; Quebrada Pringamosal, afl. Caño Blanco, $500 \mathrm{~m}$ de la escuela La Palestina, Serranía de la Macarena, Meta.

\section{Diagnosis.}

Hemibrycon guejarensis n. sp. (Fig. 3), is distinguished from most cis-Andean congeners in having ii, 7 , i dorsal-fin rays (vs. ii, 8), except $H$. taeniurus from Trinidad Island and H. jabonero from the Lake Maracaibo basin and adjacent Caribbean drainages, from which it differs in having a circular humeral spot, which originates in the second layer of pigment or pigment layer 2) (vs. humeral spot vertically elongate). In Hemibrycon guejarensis, as in other Hemibrycon species, a short branch of the canal arises at the origin of the lateral-line canal, and then crosses the humeral spot, located on the scale series just above the lateral-line canal series, the orientation of this short branch of the lateral-line systems is as follows: in the holotype of $H$. metae the canal is horizontal and crosses the upper part of the humeral spot; in $H$. guejarensis and populations from the Orinoco River Basin and Venezuelan Caribbean drainages the canal crosses the lower part of the humeral spot transversely. Also, $H$. guejarensis further differs from true $H$. metae and other nominal populations in having a longer pectoral fin: pectoral-fin tip surpassing pelvic fin insertions vs. not reaching insertions.

Description. Morphometric and meristic data in Table 1 . Body slender and elongate (mean maximum body depth $22.8 \% \mathrm{SL}$ ). Area between orbits flat. Dorsal profile of head straight to slightly concave, then slightly convex from supraoccipital to dorsal-fin origin and from last dorsal-fin ray to caudal peduncle, then straight to base of caudal fin. Ventral profile of body convex from snout to base of anal fin, straight and oblique along anal-fin base. Caudal peduncle laterally compressed. Head and snout short, jaws equal; mouth terminal, lips soft and flexible, not covering outer row of premaxillary teeth; ventral border of upper jaw straight; posterior edge of maxilla reaching anterior edge of orbit; opening of posterior nostrils vertically ovoid; opening of anterior nostrils with membranous flap.

Premaxilla short and rounded, with two rows of teeth, five teeth of outer row tricuspid, internal row with four pentacuspid teeth diminishing gradually in size laterally. Maxilla extending beneath second infraorbital, with 8-9 tricuspid teeth in a series not reaching anteroventral margin of that bone. Dentary teeth nearest symphysis largest, pentacuspid, following anterolateral teeth tricuspid, posterior-most teeth unicuspid.

Lateral line complete, perforated scales $42-50$ (47* mean $=45, n=125)$. Scale rows between dorsal-fin origin and lateral line $6-9\left(7^{*}\right.$, mean $\left.=7.1, \mathrm{n}=125\right)$; scale rows between lateral line and anal-fin origin 6-8 $\left(7^{*}\right.$ mean $\left.=6.9, \mathrm{n}=125\right)$; scale rows between lateral line and pelvic-fin insertion $6-7,\left(7^{*}\right.$, mean $=6.9, \mathrm{n}$ $=125)$. Predorsal scales 12-15, arranged in regular series $\left(13^{*}\right.$, mean $\left.=13, n=125\right)$. Anal-fin rays iii-iv, 26-30 (iii, $28^{*} ; n=125$ ). Anal-fin origin posterior to vertical through base of first dorsal-fin ray. Pectoralfin rays ii, 9-12 (*ii, 10, $\mathrm{n}=125)$. Pelvic-fin rays ii, $6^{*}$ $(n=125)$; dorsal-fin rays ii, 7 , i; in both fins last ray simple; first unbranched ray approximately one-half length of second ray, its tip reaching first bifurcation of first branched ray. Pelvic-fin origin anterior to vertical through dorsal-fin origin. Caudal fin not covered with scales, forked with short pointed lobes. Adipose fin present. Total number of vertebra 39-40 $(n=4)$.

Six infraorbitals; first infraorbital extending over dorsal surface of maxilla, bearing laterosensorial canal pores, its anterior portion has short process with blunt tip, that does not extend towards antorbital, posterodorsal margin not modified by the extension of the anterior process of second infraorbital. Supraorbital absent.

Seven or eight supraneurals between head and first proximal pterygiophores of dorsal fin, without cartilage on upper and lower margins. Eight or nine neural spines between Weberian apparatus and first proximal pterygiophores, completely ossified no cartilage between pterygiophores. Cartilage absent on union of scapular with internal surface of supracleithrum. Four proximal radials, third postcleitrum with small laminar lateral process on medial surface. Pelvic bone short, straight, blunt with cartilage at anterior tip. Pelvic bone ischial process without cartilage. Fifth and 
sixth hypurals united, posterior margin of hypurals without cartilage. Medial and proximal pterygiophores of first four anal-fin rays fused.

Pigmentation pattern in alcohol. Body dark brownish-yellow, chromatophores more densely concentrated on dorsum, most intense on head. Midlateral body with silver stripe from anterior margin of humeral spot to anterior part of the caudal peduncle and caudal spot prolonged on to middle caudal-fin rays. Humeral spot with two layers of pigment, which are independent of each other and differ in degrees of development and structure (Fig 2 and 5). The humeral spot extends over four horizontal scales of the lateral-line canal and two below it, the spot consists of two layers of pigment, one not very conspicuous that extends vertically that ventrally crosses the lateral-line canal and a second configuration of that is very conspicuous and circular with more concentrated pigments, that has an irregular edge and covers three scales vertically and one horizontally, these together generate the aspect of a rhomboidal shape, located just behind the margin posterior of the operculum. Ventral part of body light yellow. Posterior margin of scales on dorsal region of body dark. Dorsal fin without strong concentration of chromatophores along distal margin. Adipose fin dark. Caudal fin with dark chromatophores on middle rays. Anal, pectoral and pelvic fins as well as caudalfin lobes hyaline.

Color in life. Adults counter-shaded and with silvery lateral stripe highlighted in iridescent yellowishgreen, more conspicuous along the dorsal margin of the stripe; dorsal and ventral borders of stripe reddish on caudal peduncle. Dorsal margin of opercle anterior to lateral stripe intense yellow. Dorsal margin of eye yellow, similar to the color of the anterior lateral stripe borders. Infraorbital along posterior margin of orbit violet, this color extending along dorsal half of opercle. Head beneath orbit intense blue, circumscribing the third infraorbital. Scales on sides of body without melanophores, giving it a whitish or silvery appearance. Dorsal region dark green. Wide dark humeral spot, conspicuous beneath silvery lateral stripe, extending over it but with less intensity. Posterior part of caudal peduncle with dark midlateral stripe that extends onto middle caudal-fin rays. Lower caudal fin lobe and tips of both lobes red. Pectoral and pelvic fins hyaline, anal and dorsal fins with a reddish bar crossing middle parts of rays, more notable in males, distal tips of dorsal and caudal fins dark.
Secondary sexual dimorphism. Males have hooks on the anal and pelvic-fin rays. There are 12 to 15 hooks located on the middle and distal portions of unbranched and first to eighth branched anal-fin rays. All branched pelvic-fin rays have 19 to 22 small hooks all along ray's length. There are small, poorly developed hooks on the extreme distal portions of the pectoral-fin rays.

Etymology. The name guejarensis, n.sp. refers to the Güejar River Basin in Meta Department, Serranía de La Macarena, Colombia, where the type series was collected.

Distribution and habitat. This species is known only from the Güejar River Basin in Meta Department, Serranía de La Macarena, Guaviare River drainage, Orinoco River Basin in Colombia (Fig. 3). Hemibrycon guejarensis was collected along shore over sandy substrates in tributaries with flow. The transparency of the tea colored water was usually high, even after rain. The $\mathrm{pH}$ was usually around neutral (7.0-7.5), dissolved oxygen and percent saturation of oxygen values were high. The new taxon is syntopic with $A s$ tyanax n. sp. (bimaculatus group), Bryconamericus macarenae (Román-Valencia et al., 2010c), Creagrutus maculosus (Román-Valencia et al., 2010b), Characidium cf. zebra and Hemigrammus barrigonae (Eigenmann \& Henn, 1914).

\section{DISCUSSION.}

The Orinoco River Basin encompasses an enormous and heterogeneous system of freshwater ecosystems including streams draining the Andes Mountains, piedmont, vast savannahs and floodplains, and several rivers draining the Guyana Shield. So a great diversity of aquatic habitats can be found there (Lasso et al., 2016). These conditions have apparently favored development of cryptic species in some genera of Characidae, such as Astyanax (Garutti 2003), Bryconops (Machado-Allison et al. 1996) or Moenkhausia (Marinho and Langeani 2010), and to give just a few examples of endemic species described from within taxa previously considered to have widespread distributions. Western Caribbean drainages in Venezuela have similar fish faunas to that of the Lake Maracaibo Basin. Caribbean drainages east of the Paraguaná Peninsula have several narrowly endemic species but in the Unare River Basin and eastward, the similarity with the Orinoco River Basin fish fauna increases 
(Rodríguez-Olarte et al. 2009; 2011).

Populations of Hemibrycon can be found in the coastal rivers where conditions of piedmont and mountain streams are permanent (much of the Venezuelan coast is an arid desert with only season flow in streams). As more specimens and tissue samples for DNA analysis become available, we expect more and more local populations with be recognized as distinct, as we do here for the upper Guaviare River populations of what was previously considered nominal $H$. metae. The Guaviare River seems to be a particularly diverse transition zone between the Orinoco River Basin and adjacent Amazon River tributaries, with several species found there that are unknown in other regions of the Orinoco Basin; for example Chaetostoma joropo Ballen 2011 and Chrysobrycon guahibo Vanegas-Ríos et al. 2015. The recognition of the ichthyological richness of the Orinoco River Basin is essential for promoting its conservation and sustainable use, and is the basis for the evaluation of the threats faced there now and in the future (Lasso et al., 2016).

We consider populations of Hemibrycon metae from the Venezuelan Orinoco River Basin piedmont streams and Caribbean drainages to be instead either H. jabonero or $H$. taeniurus (see material examined, table 1 , figs. 1-4). The analysis of these populations indicated that all of them differ from true H. metae (holotype and topotypes) in relation to the length of the pelvic fin and the postorbital length (Table 1). These identifications differ from those of Bertaco \& Malabarba (2010), who did not consider all the measurements used in the literature, particularly the postorbital region, and who reported relatively shorter pelvic fin lengths than those we measured. Our analyses indicate that there is still unrecognized diversity of the species of Hemibrycon present in Caribbean streams.

Although Hemibrycon in the Orinoco River Basin are all morphologically very similar, cranial characters and fin lengths were the most divergent based on univariate analyses. Bertaco \& Malabarba (2010) reported a wide range of values for these characters, but we found that some of these populations are not $H$. metae but rather $H$. jabonero (which was not explicitly included in their analysis). While we do identify $H$. metae present in both Caribbean and Orinoco River basin drainages, they are not common, and not nearly as abundant as $H$. jabonero which is found throughout the basin. The values given for $H$. metae by Bertaco \& Malabarba (2010) include specimens we identify as
H. jabonero, since the two species are sympatric (see material examined).

Hemibrycon guejarensis n. sp. has a red spot on the ventral portion of the caudal peduncle in life. This characteristic has also been observed in several other species of Hemibrycon (Bertaco et al., 2007; GarciaAlzate et al.,2015; Román-Valencia et al., 2010 a; b; 2014), leading us to infer that it represents a synapomorphy for the genus. However, H. iqueima (GarciaMelo et al., 2018) does not present this character and even the model of pigmentation and osteological and tooth characters that we have observed in most Hemibrycon species.

Thomaz et al. (2015) discussed the possibility that species previously considered as Bryconamericus from Colombia, should instead be tentatively recognized as members of the genus Hemibrycon, based mainly on a molecular phylogeny. We question the identification of voucher or control specimens, for B. caucanus, $H$. boquiae, $H$. brevispinni, $H$. jabonero; such is the case of $H$. jabonero is distributed on the Caribbean coast of Venezuela (see results of this paper), not from the Magdalena River Basin in Colombia: the voucher ANSP 188918 (7404-7405 and 7410) identified as $H$. jabonero in Tomaz et al. (2015), corresponds to $H$. antioquia (Román-Valencia et al., 2013). H. jabonero was not included in the study of cis-Andean species (Bertaco \& Malabarba, 2010).

\section{ACKNOWLEDGMENTS.}

We are grateful for the support of the University of Quindío, Vice Rectory of Investigation for grants 304,357, 464 and 824 to C.R-V. \& C. G-A., which financed the study and to Idea Wild for providing field equipment and laboratory materials. For the loan of comparative material we thank: James Maclaine (BMNH), Francisco Bisbal, Marcos Guerra and Rafael Suárez (EBRG), Jose E. Castillo and Fabio Quevedo (IAvH), Francisco Provenzano and Alberto Marcano (MBUCV), Richard P. Vari and Susan L. Jewett (USNM).We wish to thank the Gonzaga, Ordanet and Javier Marin families for their help and generous hospitality during our stay at La Macarena. Cristian Román-P. (U A, Tucson, USA) elaborated Fig. 4 and gave us useful suggestions to improve the manuscript. Néstor J. Mancera (UN) and Henry Agudelo-Z (ICN$\mathrm{UN}$ ) reviewed a version of this paper. 


\section{REFERENCES}

-Arcila-M, D. K. 2008. Análisis filogenético y biogeográfico de las especies del género Hemibrycon (Characiformes, Characidae). Trabajo de grado B. Sc. Programa de Biología, Universidad del Quindío. Armenia, Colombia. 90p.

- Ballen, G. A. 2011. A new species of Chaetostoma tschudi (Siluriformes: Loricariidae) from Colombia with a definition of the $C$. anale species group. Papéis Avulsos de Zoologia, Museu de Zoologia da Universidade de São Paulo, 51: 38.

- Bertaco, V. A., L. R Malabarba., M Hidalgo \& H. Ortega. 2007. A new species of Hemibrycon (Teleostei: Characiformes: Characidae) from the río Ucayali drainage, Sierra del Divisor, Perú. Neotropical Ichthyology, 5:251-257.

- Bertaco, V.A. \& L.R. Malabarba. 2010. A review of the Cis-Andean species of Hemibrycon Günther (Teleostei: Characiformes: Characidae: Stevardiinae) with description of two new species. Neotropical Ichthyology, 8:737-770.

- Brooks, T., N. de Silva, M. Foster, M. Hoffmann, D. Knox, P. Langhammer, J. Pilgrim, N. Ratledge \& A. Sweeting (editors). Biodiversity hotspots. Conservation International, Arlington, Virginia. (Available from: www.biodiversityhotspots.org/xp/

hotspots/chilean_forests/Pages/biodiversity.aspx)

- Eigenmann, C. H. \& A. W. Henn. 1914. On new species of fishes from Colombia, Ecuador, and Brazil. Contribution Zoology Laboratory Indiana University Studies, 24: 231-234.

Feckler, A., Jochen P. Zubrod J. P., Thielsch A., Schwenk, K., Schulz, R. \& Bundschuh M. 2014. Cryptic species diversity: an overlooked factor in environmental management? Journal of Applied Ecology, 51, 958-967.

- Fink, W.L. \& S.H. Weitzman. 1974. The So-called Cheirodontine fishes of Central America with Descriptions of two new species (Pisces: Characidae). Smithsonian Contribution to Zoology, 172: 1-46.

- Garcia-Alzate, C.A, Román-Valencia, C. \& Taphorn D. C. 2015.New species of Hemibrycon (Characiformes: Characidae) from Sierra Nevada of Santa Marta, Caribe sea, Colombia. Cuadernos de Investigación UNED, 7: 89-97.

- García-Melo, J.E., J. G. Albornoz-Garzón, L. J. García-Melo, F. A. Villa-Navarro, J. A. Maldonado-Ocampo 2018. A new Species of Hemibrycon (Characiformes, Characidae, Stevardiinae) from the upper Magdalena River basin in Colombia. Journal of Fish Biology, 92:1929-1955.

- Garutti, V. 2003. Revalidação de Astyanax rupununi Fowler, 1914 (Teleostei, Characidae) e descrição de duas espécies novas para o gênero. Papéis Avulsos de Zoologia, Museu de Zoologia da Universidade de São Paulo, 43: 1-9.

- Günther, A. 1864. Catalogue of the fishes in the British Museum. Catalogue of the physostomi, containing the families Siluridae, Characinidae, Haplochitonidae, Sternoptychidae, Scopelidae, Stomiatidae in the collection of the British Museum. Catalogue fishes, 5:1-455.

- Lasso, C.A., Machado, A. \& D.C Taphorn. 2016. Fishes and aquatic habitats of the Orinoco River Basin: diversity and conservation. Journal of Fish Biology. doi:10.1111/jfb.13010, available online at wileyonlinelibrary.com

- Machado-Allison, A., B. Chernoff and P. A. Buckup. 1996. Bryconops humeralis y B. vibex, dos nuevas especies del genero Bryconops Kner (1858) para Venezuela. Acta Biológica Venezuelica, 16: 43-58.

- Marinho, M. M. F. and F. Langeani. 2010. A new species of Moenkhausia from the rio Amazonas and rio Orinoco basins (Characiformes: Characidae). Zootaxa, 2577: 57-68.

- Rodríguez-Olarte, D., Taphorn, D.C. and Lobón Cerviá, J., 2009. Patterns of freshwater fishes of the Caribbean versant of Venezuela. International Review of Hydrobiology, 94: 67-90.

- Rodríguez-Olarte, D., Taphorn, D.C. \& J. Lobón-Cervia. 2011. Do protected areas conserve neotropical freshwater fishes? A case study of a biogeographic province in Venezuela. Animal Biodiversity and Conservation, 34.2:273-285.

- Román-Valencia, C. 2001. Redescripción de Hemibrycon boquiae (Pisces: Characidae), especie endémica de la Quebrada Boquia, cuenca Río Quindío, Alto Cauca, Colombia. Dahlia (Revista Asociación Colombi- 
ana de Ictiólogos), 4: 27-32.

- Román-Valencia, C. \& R. I. Ruiz-C. 2007. Una nueva especie de pez del género Hemibrycon (Characiformes: Characidae) del Alto Río Atrato, Noroccidente de Colombia. Caldasia, 29: 121-131.

- Román-Valencia, C. \& D. K. Arcila-Mesa. 2008. Hemibrycon rafaelense n.sp. (Characiformes, Characidae), a new species from the upper Cauca River, with keys to Colombian species. Animal Biodiversity and Conservation, 31: 67-75.

- Román-Valencia, C. \& D.K. Arcila-Mesa. 2009. Two new species of Hemibrycon (Characiformes: Characidae) from the Magdalena river, Colombia. Animal Biodiversity and Conservation, 32: 77-87.

- Román-Valencia, C. \& D.K Arcila-Mesa. 2010. Five new species Hemibrycon (Characiformes: Characidae) from the Magdalena River Basin, Colombia. International Tropical Biology, 58: 339-356.

- Román-Valencia, C., R. I. Ruiz-C. \& R. Barriga. 2006. Una nueva especie de pez del género Hemibrycon (Characiformes: Characidae). International Tropical Biology, 54: 209-217.

- Román-Valencia, C., R. I Ruiz-C. \& R. Barriga. 2007. Redescripción de Hemibrycon orcesi Böhlke, 1958 y H. polyodon (Günther, 1864) (Teleostei, Characidae), incluye clave para las especies de Hemibrycon en Ecuador. Animal Biodiversity and Conservation, 30: 179-188.

- Román-Valencia, C., J. A Vanegas-Ríos, M. D García. 2009a. Análisis comparado de las especies del género Bryconamericus (Teleostei: Characidae) en la cuenca de los ríos Cauca-Magdalena y Ranchería, Colombia. Revista Mexicana de Biodiversidad, 80: 465-482.

- Román-Valencia, C., R. I Ruiz-C., C. García-Alzate \& D. C. Taphorn. 2009b. Hemibrycon santamartae: a new species from the Rancheria river of Eastern Caribbean Colombia (Characiformes: Characidae). Revista de Investigaciones, Universidad del Quindío, 19: 144-150.

- Román-Valencia, C., D. K. Arcila-Mesa \& M. D. García. 2009c. Diversidad fenotípica en peces del género Hemibrycon (Characiformes: Characidae) del sistema del río Magdalena-Cauca, Colombia. Brenesia, 7172: $27-40$.

- Román-Valencia, C., C. García-Alzate, R. I. Ruiz-C. \& D.C. Taphorn. 2010a. New species of Hemibrycon (Teleostei, Characiformes, Characidae) from the Roble River, Alto Cauca, Colombia, with a key to species known from the Magdalena - Cauca River Basin. Vertebrate Zoology, 60: 99-105.

- Román-Valencia, C., C. A. García-Alzate, Ruiz-C R. \& D. C. Taphorn. 2010b. A new species of Creagrutus (Characiformes, Characidae) from the Güejar River, Orinoco Basin, Colombia. Ichthyological Exploration of Freshwaters, 2:87-95.

- Román-Valencia, C., C. A García-Alzate, R. I. Ruiz-C \& D. C. Taphorn. 2010c. Bryconamericus macarenae n. sp. (Characiformes, Characidae) from the Güejar River, Macarena mountain range, Colombia. Animal Biodiversity and Conservation, 33:195-203.

- Román-Valencia, C., Ruiz-C. R. I., Taphorn, D. C., Mancera-Rodríguez, N.J. \& García-Alzate, C.A., 2013. Three new species of Hemibrycon (Characiformes: Characidae) from the Magdalena River Basin, Colombia. Revista de Biologia Tropical, 61:1365-1387.

- Román-Valencia, C., R. I. Ruiz-C C., D. C. Taphorn \&.C. A García-Alzate. 2014. A new species of Hemibrycon (Characiformes, Characidae) from the upper San Juan River drainage, Pacific versant, Colombia. ZooKeys, 454:109-125.

- Román-Valencia, C., R. I. Ruiz-C, D. C. Taphorn B., P. Jiménez-Prado \& C. A. Garcia-Alzate. 2015. A new species of Bryconamericus (Characiformes, Stevardiinae,Characidae) from Pacific versant, Northwestern of Ecuador, South America. Animal Biodiversiy and Conservation, 38.2:241-252.

- Ruiz-C., R.I. \& C. Román-Valencia.2006. Osteología de Astyanax aurocaudatus Eigenmann, 1913 (Pisces: Characidae), con notas sobre la validez de Carlastyanax Géry, 1972. Animal Biodiversity and Conservation, 29: 49-64.

- Ruiz-C, C Román-Valencia, D. C. Taphorn, P. A. Buckup \& H. Ortega.2018. Revision of the Astyanax orthodus species-group (Teleostei: Characidae) with descriptions of three new species. European Journal of Taxonomy, 402: 1-45.

- Sabaj Pérez, M.H. (editor). 2016. Standard symbolic codes for institutional resource collections in herpetology and ichthyology: an online reference. Version 2.0 (8 November 2016). Electronically accessible at http://www.asih.org/, American Society of Ichthyologists and Herpetologists, Washington, D.C. 
- Song, J. \& L. R. Parenti. 1995. Clearing and staining whole fish specimens for simultaneous demonstration of bone, cartilage and nerves. Copeia, 1995: 114-118.

- Taylor, W. R. \& G. C. van Dyke. 1985. Revised procedures for staining and clearing small fishes and other vertebrates for bone and cartilage study. Cybium, 9: 107-119.

- Thomaz, T.A., Arcila, D., Ortiz G., Malabarba, L.R., 2015. Molecular phylogeny of the subfamily Stevardiinae Gill, 1858 (Characiformes: Characidae): classification and the evolution of reproductive traits. BMC Evolutionary Biology, 15:1-26.

- Vanegas-Ríos, J. A., A. Urbano-Bonilla and M. de las M. Azpelicueta 2015. Chrysobrycon guahibo, a new species from the Orinoco River basin, with a distribution expansion of the genus (Teleostei: Characidae). Ichthyological Exploration of Freshwaters, 26: 171-182.

- Vari, R.P. \& D. J. Siebert. 1990. A new unusually sexually dimorphic species of Bryconamericus (Pisces: Ostariophysi: Characidae) from the Peruvian Amazon. Proceeding Biological Society Washington, 103: 516-524.

- Vari, R.1995. The neotropical fish family Ctenoluciidae (Teleostei: Ostariophysi: Characiformes): supra and intrafamilial phylogenetic relationships, with a revisionary study. Smithsonian Contribution to Zoology, 564:1-96.

- Weitzman, S.H.1962. The osteology of Brycon meeki, a generalized characid fish, with an osteological definition of the family. Stanford Ichthyological Bulletin, 8: 1-77. 


\section{FIGURE LEGENDS}

Fig. 1. Discriminant analysis of morphological data for: H. metae, H. guejarensis n. sp., Hemibrycon sp., Hemibrycon jabonero and $H$. taeniurus.

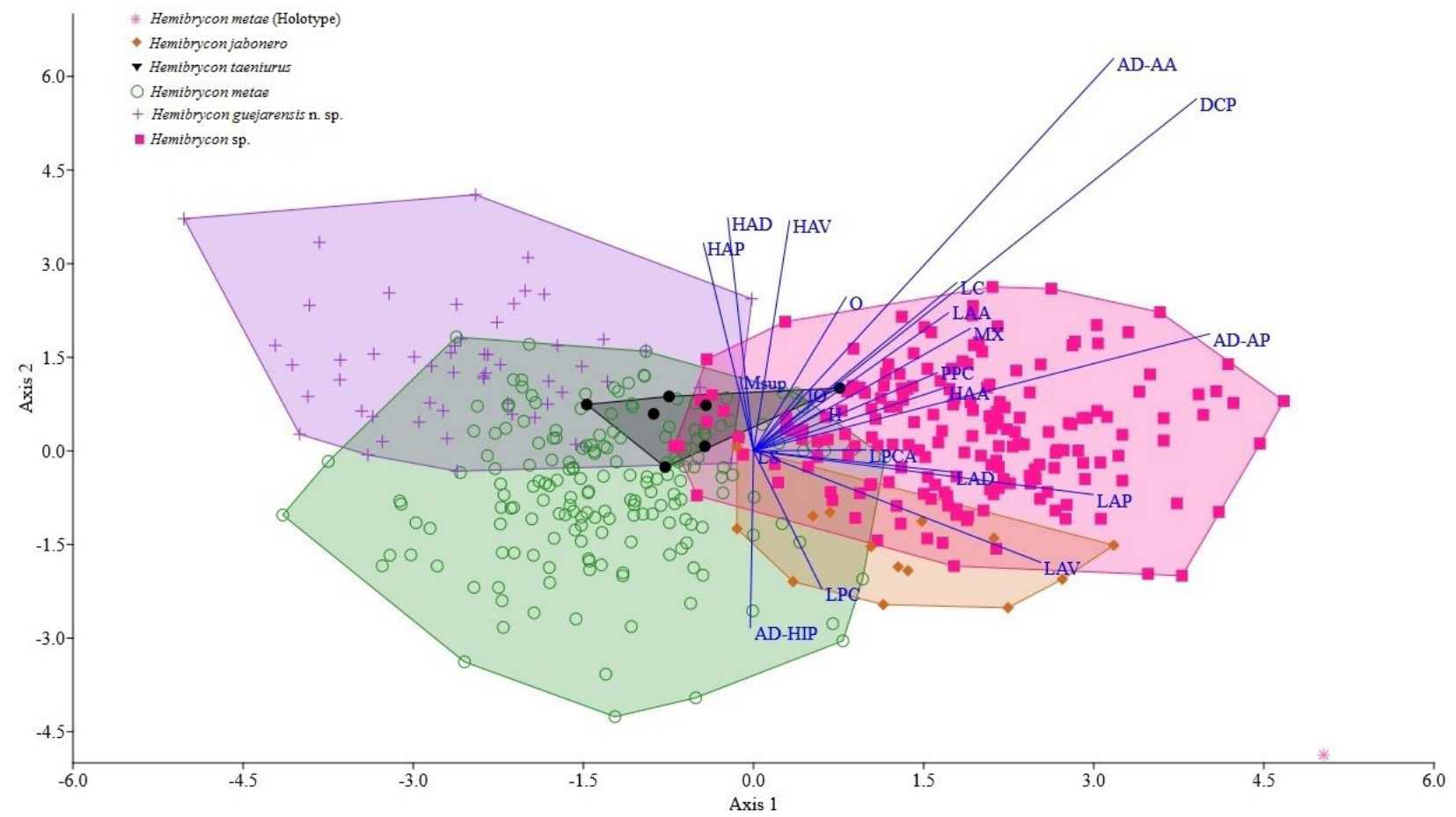


Fig. 2. Distribution of pigment in the humeral region of Hemibrycon species. A. H. metae (Holotype), B. H. metae, C. H. guejarensis n. sp., D. H. taeniurus, E. H. jabonero.

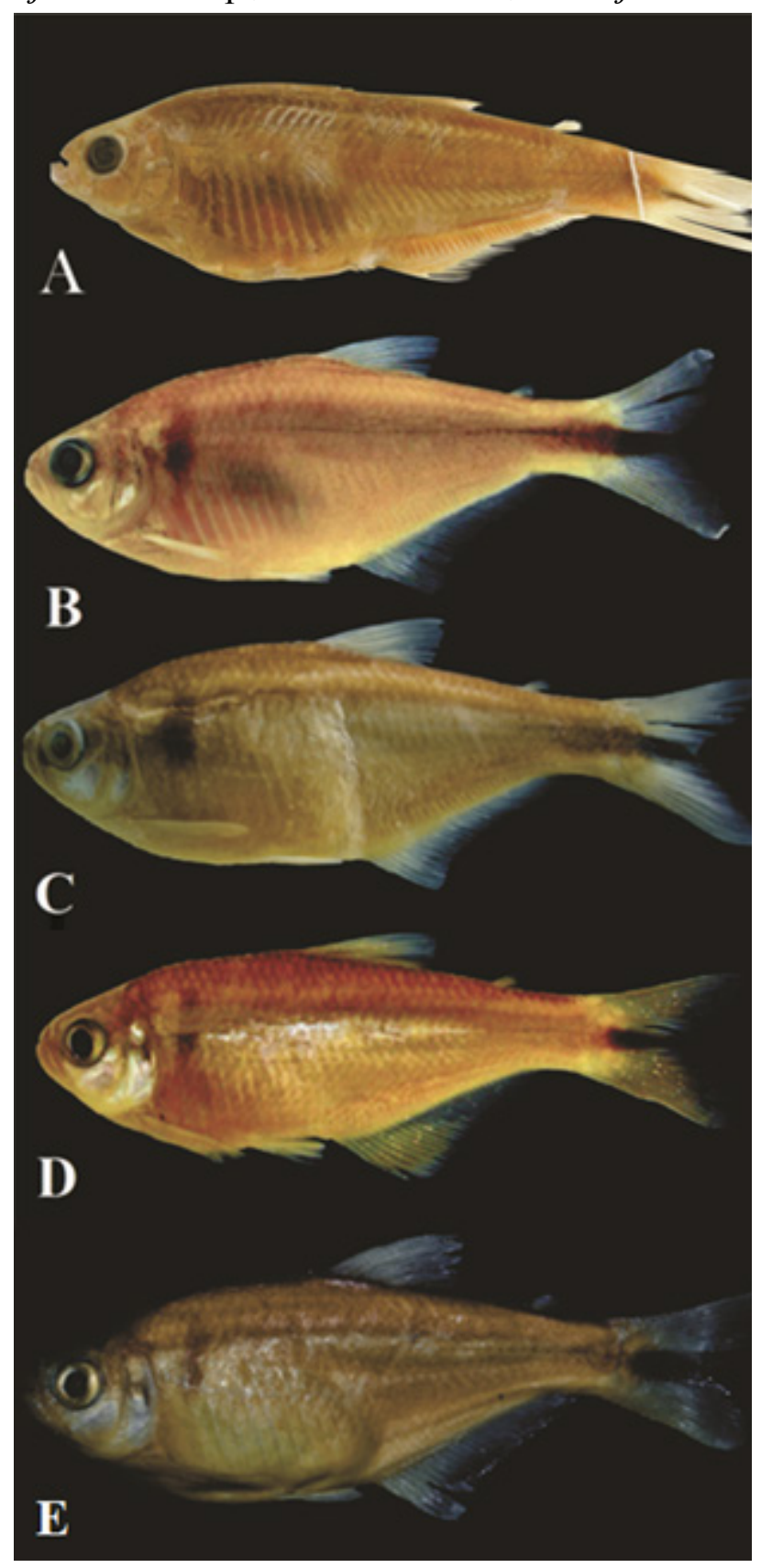


Fig. 3. Hemibrycon guejarensis n. sp., IUQ 2484, 78.33 mm SL; female, Meta, Vista Hermosa County, Buenavista village, Orinoco River Basin, Colombia. Scale $=1 \mathrm{~cm}$.

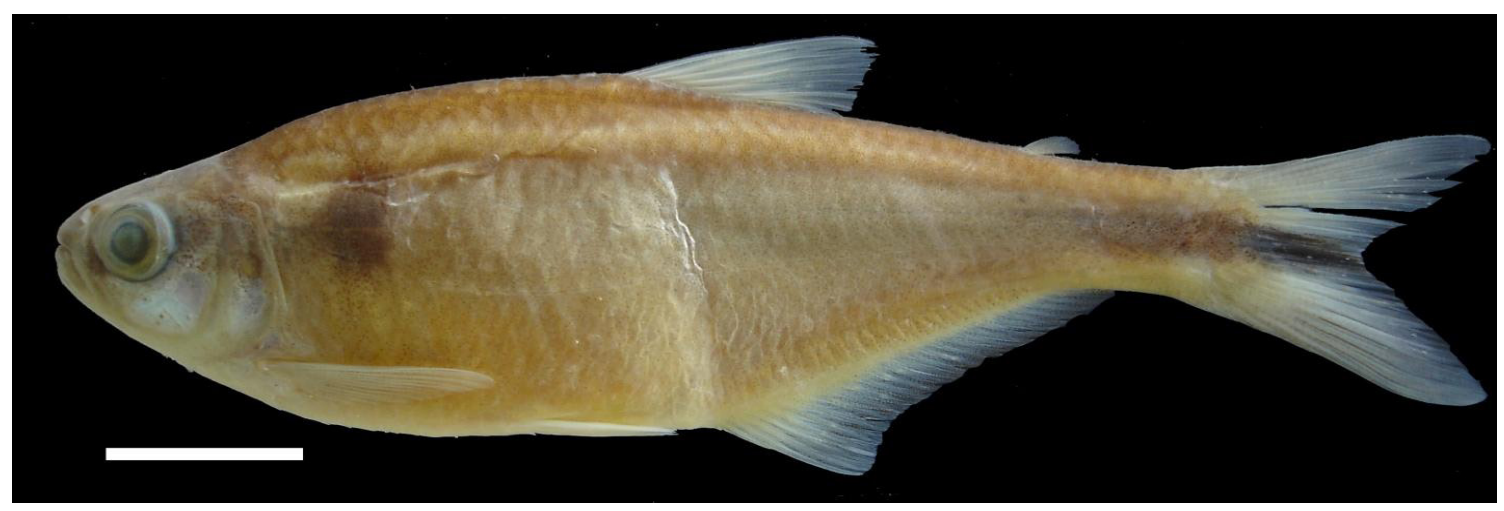

Fig. 4 Distribution of Hemibrycon guejarensis n. sp. (•), H. metae $(\bullet)$, H. jabonero $(\boldsymbol{\square})$ and $H$. taeniurus $\nabla$.

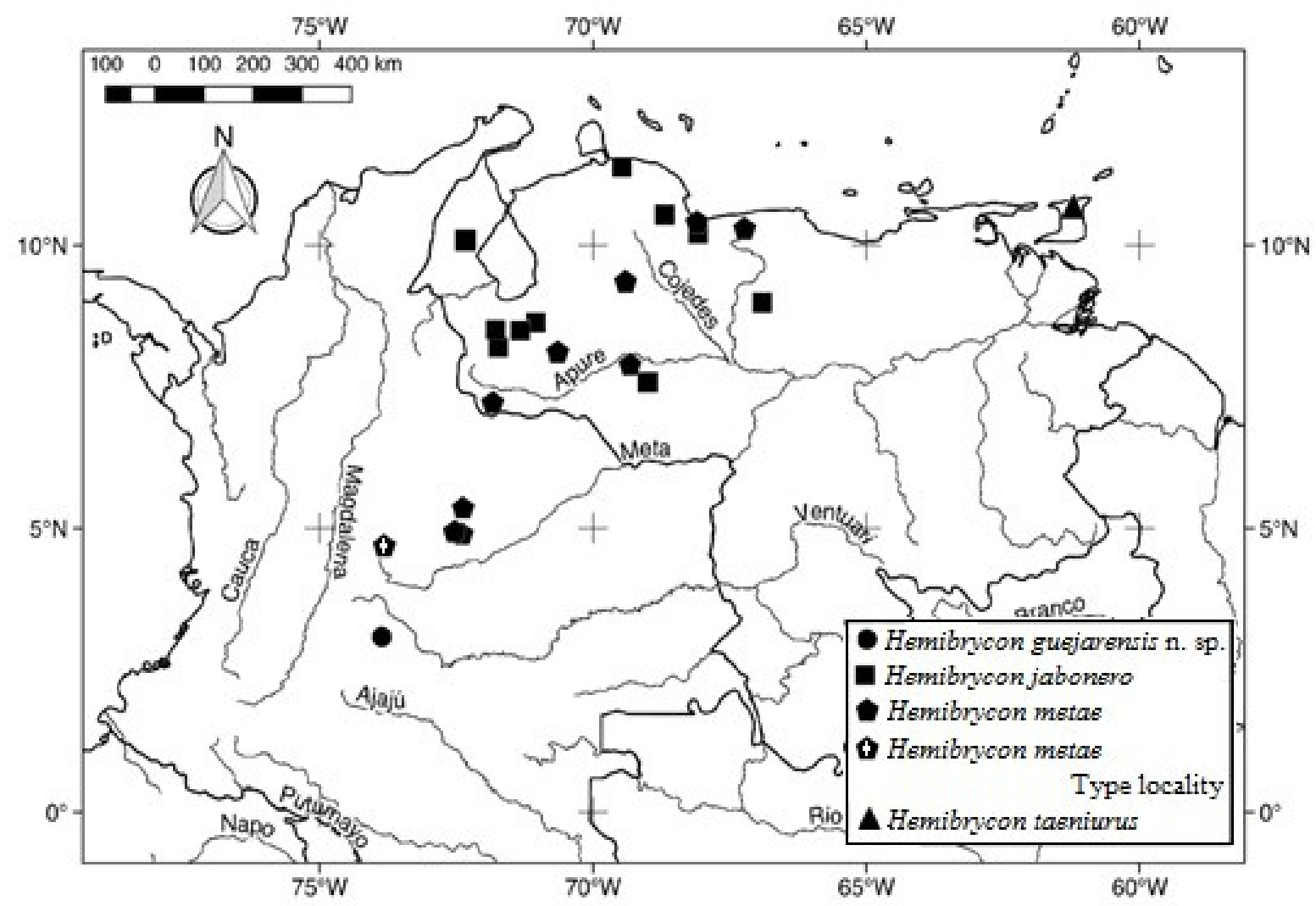




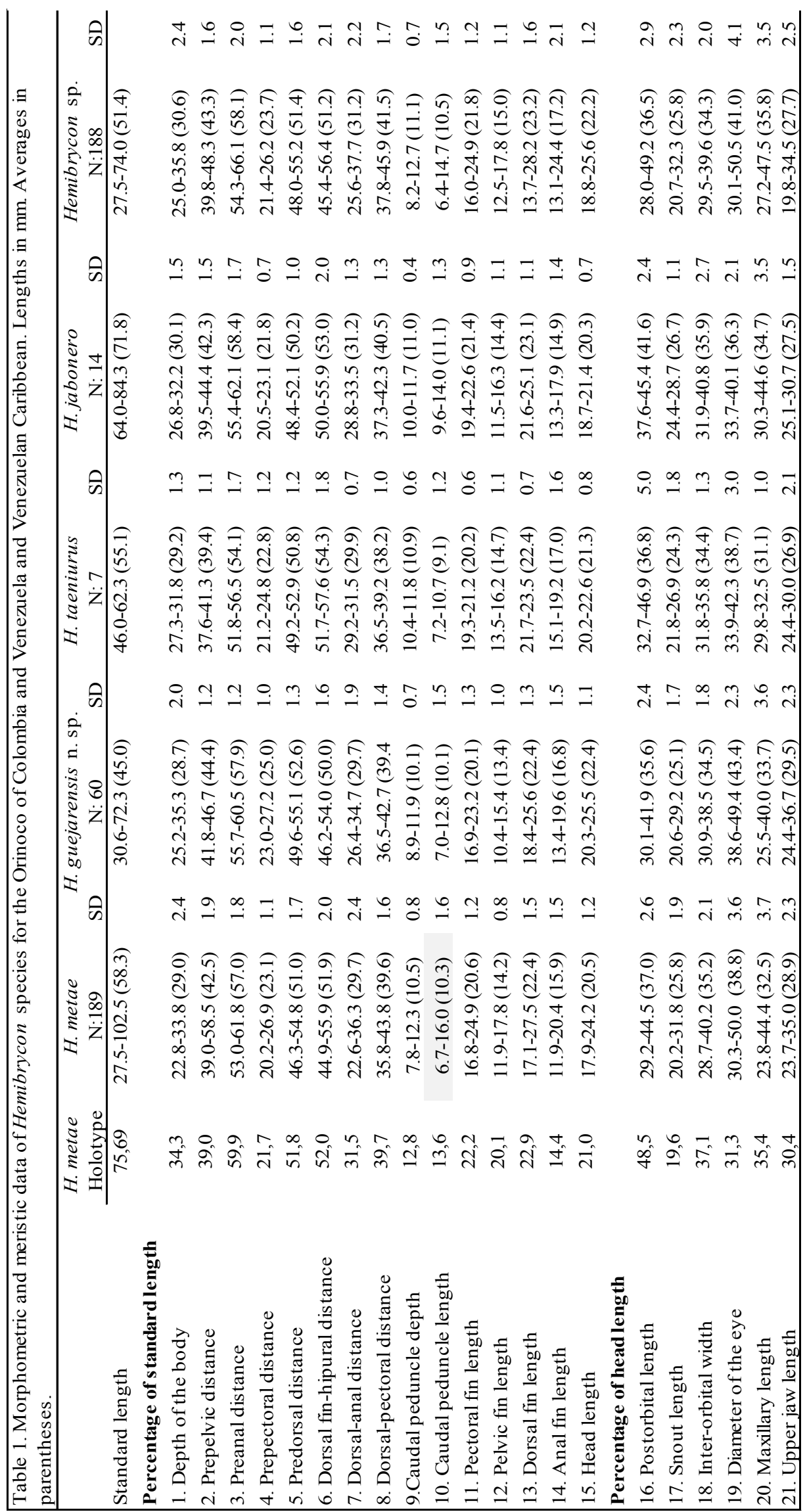


Table 2. Permanova data from Hemibrycon populations present in the Orinoco and the Venezuelan Caribbean

\begin{tabular}{|c|c|c|c|c|c|c|}
\hline & $\begin{array}{c}\text { H. guejarensis } \\
\ldots\end{array}$ & $\begin{array}{l}\text { H. metae } \\
\text { (Holotype) }\end{array}$ & H. metae & $\begin{array}{l}\text { Hemibrycon } \\
\text { sp. }\end{array}$ & H. jabonero & $\begin{array}{l}\text { H. tae- } \\
\text { niurus }\end{array}$ \\
\hline guejarensis n. sp. & & 0.0193 & 0.0001 & 0.0001 & 0.0001 & 0.0001 \\
\hline metae (Holotype) & 0.0193 & & 0.0168 & 0.034 & 0.0671 & 0.1248 \\
\hline metae & 0.0001 & 0.0168 & & 0.0001 & 0.0035 & 0.0005 \\
\hline emibrycon sp. & 0.0001 & 0.034 & 0.0001 & & 0.0003 & 0.0001 \\
\hline jabonero & 0.0001 & 0.0671 & 0.0035 & 0.0003 & & 0.0001 \\
\hline taeniurus & 0.0001 & 0.1248 & 0.0005 & 0.0001 & 0.0001 & \\
\hline
\end{tabular}

